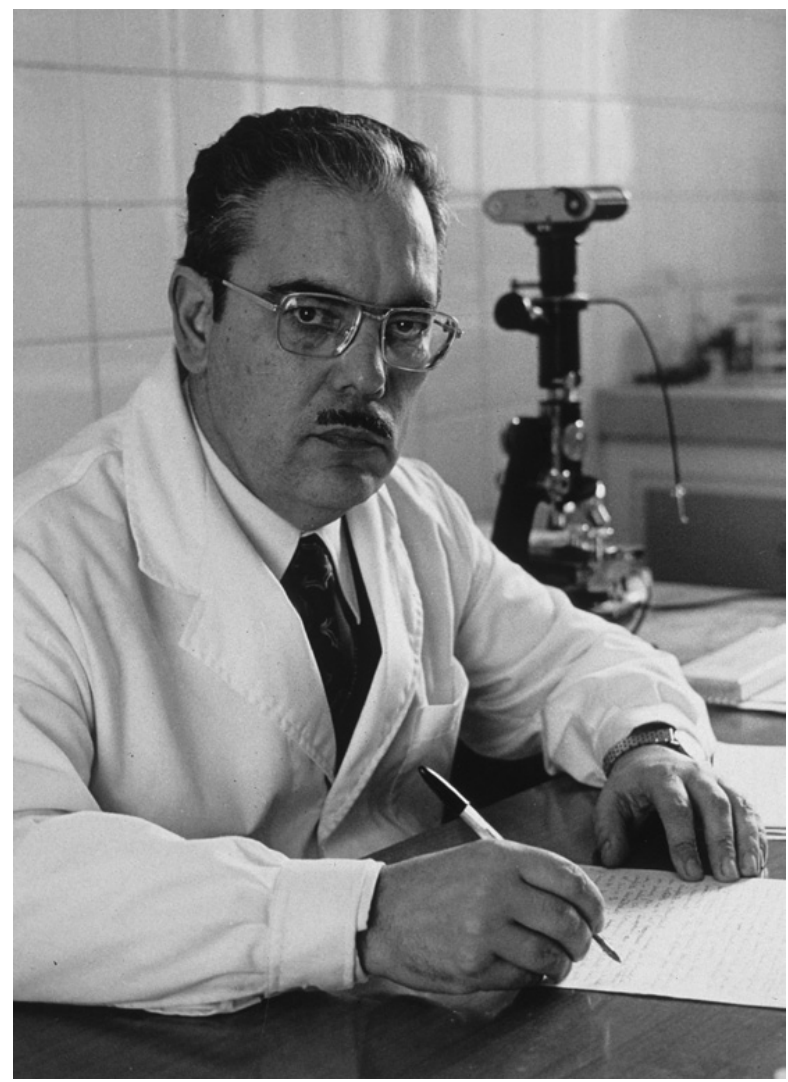

\title{
Francisco Vives Galmés (Manacor, 1926 - Palma de Mallorca, 2015)
}

True delight in research, curiosity and fine intuition are crucial features for any scientist. When these characteristics are accompanied by an immense capacity for work and infinite patience and skill, what you have is the portrait of an integral scientist such as Dr Francisco Vives, who died unexpectedly in his beloved Majorca on 2 March 2015 after a short disease. He was 88 years old.

With the death of Dr. Vives, the field of marine biology has lost a pioneer and father of zooplankton studies in Spain and the mentor of generations of researchers on marine zooplankton biology, systematics and taxonomy. It is likely his passion for marine biology was aroused when in 1949 he participated in an introductory course on marine fisheries organized by the Instituto de Biología Aplicada (Institute of Applied Biology, IBA) at the University of Barcelona, where he studied Natural Sciences. The course included, aside from fish biology, an introduction to taxonomy and ecology of plankton in relation to fishery produc- tion, and was tutored, amongst others, by Prof. Garcia del Cid, Chair of Zoology and founder of the IBA. A young Ramon Margalef (then recently graduated from the same university) was in charge of the field and laboratory work. This course and others of a similar nature were the cradle for a pioneering group of marine biologists and oceanographers, the first generation of Spanish marine scientists who staffed the various laboratories of a recently created Instituto de Investigaciones Pesqueras (Institute of Fisheries Research, IIP), successor of the IBA and linked to the marine biology section of the Patronato Juan de la Cierva de Investigación Científica y Técnica, in turn a branch of the Spanish National Research Council (CSIC).

The main scientific interest of Dr Vives, aside from early works on the interaction between primary productivity and fisheries, included systematic and ecological studies of practically all the taxonomic groups of zooplankton, from jellyfish to tunicates (and of course his beloved copepods), as well as the larval forms of non- 
planktonic organisms. His studies covered not only the Iberian regional seas but also the eastern Mediterranean and the Atlantic, which he sampled either as an invited scientist on international oceanographic cruises (R/V Jean Charcot, Meteor, etc.) or as the head of cruises of the first integrated oceanographic programmes on board Spanish vessels that he helped to design, the R/V Cornide de Saavedra and the R/V García del Cid.

After his graduation in 1950 Francisco Vives obtained a post at the coastal laboratory of the IIP in Vinaroz (Castellón), where he studied the overexploited fishery of the area. In 1955 he moved to the laboratories of Vigo, in the NW corner of Spain, where he studied the plankton of the Ría and its relation to fisheries production and mussel culture. In 1960 he returned to the new laboratory in Castellón, where he carried out a vast study of the ecology and systematics of neritic zooplankton in the western Mediterranean. This study formed the basis of a $\mathrm{PhD}$ thesis that he defended in 1970. In 1962 he returned to Barcelona, where the IIP occupied a new building. There he was a prolific head of research projects in the area near Barcelona, in the Atlantic Ocean and in the Gulf of Biscay. But his greatest achievement was his decisive action in the training of young scientists, future experts in ecology and systematics of zooplankton groups as diverse as cnidarians, copepods, chaetognaths, larval fish and crustaceans, which were the germ of research groups that are now very active in institutes and universities in Spain and overseas. In 1987 he moved definitively to his native island of Majorca, first sharing the facilities of the Instituto Español de Oceanografía (Spanish Institute of Oceanography), and later joining the Instituto Mediterráneo de Estudios Avanzados (Mediterranean Institute for Advanced Studies, IMEDEA, CSIC), where he led several research projects related to the hydrography and plankton ecology of the Balearic Sea until his official retirement in 1991.

When I first met Dr Vives, in September 1966, the scarcity of resources at the IIP had made him the de- signer and builder of much of his scientific equipment, from plankton sampling devices (every possible type of plankton net, with the corresponding opening-closing mechanism) to special tools for micromanipulation of zooplankton specimens (dissecting ultrafine needles and forceps, counting chambers, etc.). Everything was made with an astonishing economy of means, probably resulting from his painstaking adaptation to the shortages suffered during the Spanish war. His care with the reagents and scientific material as compared with the extravagance and spendthrift of some colleagues and of most of the students was legendary, and his saying "S'abundància crea es dispendi" (abundance leads to waste) became famous at the IIP.

$\mathrm{He}$ only retired in theory, remaining as active as ever as an emeritus at IMEDEA and continuing his research until the last moment. Luckily, he was able to see the conclusion of his great project, the synthesis of the marine pelagic copepod fauna of the Iberian Peninsula and adjacent seas, a monumental two-volume treatise published by the Museo Nacional de Ciencias Naturales (CSIC) (National Museum of Natural Sciences) in the series Fauna Ibérica. The first volume, dealing with calanoid copepods, was published in 2007 and was followed three years later by the volume corresponding to non-calanoid copepods. In total, they added up to 2000 pages with about 4500 original drawings.

The absence of Francisco Vices leaves a great void in his family, friends, colleagues and former students, and in the whole zooplankton community, although the great pain of his loss should be partly damped by the legacy of his work and the memory of his human qualities, including his kindness, generosity of ideas and friendliness. He leaves a wife, Francisca Llinas, two daughters and four granddaughters.

Miguel Alcaraz Institut de Ciències del Mar, CSIC 


\section{Francisco Vives Galmés (Manacor, 1926 - Palma de Mallorca, 2015}

Verdadero placer en la investigación, curiosidad y fina intuición son características fundamentales para cualquier científico. Cuando éstas se acompañan de una inmensa capacidad de trabajo e infinita paciencia y habilidad, se obtiene el retrato de un científico integral como el Dr. Francisco Vives, que murió inesperadamente el 2 de marzo de 2015 en su querida Mallorca después de una corta enfermedad. Tenía 88 años de edad.

Con la muerte de Francisco Vives el campo de la biología marina ha perdido un pionero, padre de los estudios modernos de zooplancton en España, y mentor de generaciones de investigadores en biología, sistemática y taxonomía del zooplancton marino. La pasión del Dr. Vives por la biología marina despertó probablemente cuando en 1949 asistió a un curso de introducción a las pesquerías marinas organizado por el Instituto de Biología Aplicada en la Universidad de Barcelona, donde estudió Ciencias Naturales. El curso incluía, además de biología de peces, una introducción a la taxonomía y ecología de plancton en relación con la producción pesquera, y entre otros profesores contaba con el Dr. García del Cid, Catedrático de zoología y fundador del Instituto de Biología Aplicada. Un joven Ramon Margalef (entonces recién graduado en la misma Universidad) fue el encargado de las prácticas. Este curso y otros de similar naturaleza dieron nacimiento a un grupo pionero de biólogos marinos y oceanógrafos, la generación de científicos marinos españoles que nutrió los diferentes laboratorios del recientemente creado Instituto de Investigaciones Pesqueras, sucesor del Instituto de Biología Aplicada y vinculado a la sección de biología marina del Patronato Juan de la Cierva de Investigación Científica y Técnica, a su vez una rama del Consejo Superior de Investigaciones Científicas (CSIC).

El principal interés científico del Dr. Vives, más allá de sus primeros trabajos sobre la interacción entre productividad primaria y pesquerías, incluyó estudios sistemáticos y ecológicos dirigidos a prácticamente todos los grupos taxonómicos de zooplancton, desde medusas a tunicados (y por supuesto sus favoritos, los copépodos), así como a las formas larvarias de organismos no planctónicos. Sus estudios abarcaron no sólo los mares regionales ibéricos, sino el Mediterráneo Oriental y el Atlántico, ya fuese como científico invitado en cruceros oceanográficos internacionales (B/O Jean Charcot, Meteor, etc.) o como jefe en las campañas de los primeros programas oceanográficos integrados a bordo de buques de investigación españoles en cuyo diseño participó, como el B/O Cornide de Saavedra o el B/O García del Cid.

Después de su graduación en 1950 Francisco Vives obtuvo una plaza en el laboratorio costero del Instituto de Investigaciones Pesqueras en Vinaroz (Castellón) donde colaboró en el estudio de la pesquería sobreexplotada de la zona. Unos años más tarde (1955) se trasladó sucesivamente a los laboratorios de Vigo, en el noroeste de España, donde estudió el plancton de la Ría y su relación con la producción pesquera y el cultivo de mejillones, para trasladarse en 1960 al nuevo laboratorio de Castellón. Allí llevó a cabo un amplio estudio sobre la ecología y sistemática del zooplancton nerítico del Mediterráneo occidental que fue la columna vertebral de su Tesis Doctoral, defendida en 1970. En 1962 regresó a Barcelona, donde el Instituto de Investigaciones Pesqueras contaba con un nuevo edificio. Allí desarrolló una fructífera labor en la dirección de proyectos de investigación oceanográfica tanto en las aguas próximas a Barcelona, como en el Atlántico y el Cantábrico. Pero sobre todo debe destacarse su decidida acción en la formación de jóvenes científicos, futuros expertos en ecología y sistemática de grupos de zooplancton tan dispares como cnidarios, copépodos, quetognatos, larvas de peces o crustáceos, etc., que fueron el germen de grupos de investigación actualmente muy activos en institutos científicos y universidades españolas y extrajeras. En 1987 se trasladó definitivamente en comisión de servicio a su isla natal, Mallorca, primero como invitado por el Instituto Español de Oceanografía (IEO), y más tarde incorporado al Instituto Mediterráneo de Estudios Avanzados (IMEDEA, CSIC), donde lideró diferentes proyectos de investigación relacionados con la hidrografía y la ecología del plancton del Mar Balear hasta su retiro oficial en 1991.

Cuando lo conocí, en septiembre de 1966, la escasez de recursos le obligaba a diseñar y construir él mismo parte del equipo científico, desde dispositivos de muestreo de plancton (todos los tipos posibles de redes de plancton, incluyendo los mecanismos de apertura y cierre) a aparatos para medir la biomasa y facilitar la micromanipulación de muestras de zooplancton (cubetas aforadas, agujas de disección ultrafinas y pinzas, cámaras de recuento, etc.). Todo se hacía con una increíble economía de medios, probablemente consecuencia de su penosa adaptación a la escasez sufrida durante la guerra. El cuidado con que utilizaba los reactivos y el material científico en comparación con la extravagancia y espíritu derrochador de algunos colegas y de la mayoría de los estudiantes era legendaria, y su frase "S'abundància crea es dispendi" (La abundancia crea el dispendio) se hizo famosa en el Instituto.

Su retiro era teórico. Permaneció como emérito en el IMEDEA, tan activo como siempre y continuando su investigación hasta el último momento. Afortunadamente vio su gran proyecto científico concluído: la síntesis de la fauna de copépodos pelágicos marinos de la Península Ibérica y mares adyacentes, un monumental tratado en dos volúmenes publicado por el Museo Nacional de Ciencias Naturales (CSIC) en la serie Fauna Ibérica. El primero de ellos, un volumen dedicado a los copépodos Calanoides, fue publicado en 2007, seguido tres años más tarde por el volumen correspondiente 
a los No Calanoides. En total, unas 2.000 páginas y 4.500 ilustraciones originales.

La ausencia de Francisco Vives deja un gran vacío en su familia, amigos, colegas y ex alumnos, y en toda la comunidad de estudiosos del zooplancton, aunque el gran dolor por su falta debiera ser en parte amortiguado por el legado de su obra y el recuerdo de sus cualida- des humanas entre las que destacaban su amabilidad, generosidad de ideas y carácter amistoso. Deja una esposa, Francisca Llinàs, dos hijas, y cuatro nietos.

Miguel Alcaraz Institut de Ciències del Mar (CSIC) 